\title{
Catalytic Wet Air Oxidation of High BPA Concentration Over Iron based Catalyst Supported on Orthophosphate
}

\author{
Fatiha Kaissouni ${ }^{1}$, Rachid Brahmi2 ${ }^{2 *}$, Mohamed Zbair ${ }^{1}$, Gwendoline Lafaye ${ }^{4}$, Zouhair El Assal ${ }^{3}$, \\ Laurence Pirault-Roy ${ }^{4}$, Jacques Barbier Junior ${ }^{4}$, Abdelkrim Elaissi ${ }^{1}$, Mohammed Bensitel ${ }^{1}$, \\ Mohammed Baalala ${ }^{1}$
}

\section{${ }^{1}$ Laboratory of Catalysis and Corrosion of Materials, Department of Chemistry, University}

Chouaïb Doukkali, Avenue des Facultés, 24000 El Jadida -Morocco.

${ }^{2}$ Laboratory of Coordination and Analytical Chemistry (LCCA), University Chouaïb Doukkali, Avenue des Facultés, 24000 El Jadida -Morocco.

${ }^{3}$ Faculty of Technology, Environmental and Chemical Engineering, University of Oulu, P. O. Box 4300, FI-90014 Oulu, Finland.

${ }^{4}$ IC2MP UMR 7285 CNRS, University of Poitiers, 4 rue Michel Brunet, 86022 Poitiers Cedex, France.

* Corresponding author: rachid.brahmi@univ-poitiers.fr

\section{Acknowledgments}

We gratefully acknowledge the financial support provided by the European communities (FEDER), the "Region Nouvelle Aquitaine", and the Project Partenariats Hubert Curien (PHC) Maghreb program (16MAG11) for funding Miss Kaissouni's internships at IC2MP, Poitiers-France. 


\section{Abstract}

The catalytic performance of Fe supported on nickel phosphate (NiP) was evaluated for the removal of Bisphenol A (BPA) by catalytic wet air oxidation (CWAO) at $140^{\circ} \mathrm{C}$ and 25 bar of pure oxygen pressure. The prepared $\mathrm{NiP}$ and $\mathrm{Fe} / \mathrm{NiP}$ materials were fully characterized by $\mathrm{XRD}, \mathrm{N}_{2}-$ physisorption, $\mathrm{H}_{2}-\mathrm{TPR}$, TEM, and ICP analysis. Iron (Fe/NiP) impregnation of $\mathrm{NiP}$ support enhanced the BPA removal efficiency from $37.0 \%$ to $99.6 \%$ when CWAO was performed. This catalyst was highly stable given the operating conditions of acidic medium, high temperature and high pressure. The Fe/NiP catalyst showed an outstanding catalytic activity for oxidation of BPA, achieving almost complete removal of BPA in $180 \mathrm{~min}$ at a concentration of $300 \mathrm{mg} / \mathrm{L}$, using $4 \mathrm{~g} / \mathrm{L}$ of Fe/NiP. No iron leaching was detected after the CWAO of BPA. The stability of Fe/NiP was performed over three consecutive cycles, noting that BPA conversion was not affected and iron leaching was negligible. Therefore, this catalyst (Fe/NiP) could be considered as an innocuous and effective long-lasting catalyst for the oxidation of harmful organic molecules.

Keywords: Bisphenol A; CWAO; Oxidation; Catalyst; iron-Nickel Phosphate; Environment.

\section{Abbreviations:}

8

(1)

\section{1}

2

3

\section{4} 55 56 7 58 9 6 a

$$
\begin{array}{ll}
\text { WAO } & \text { : Wet Air Oxidation } \\
\text { CWAO } & \text { : Catalytic Wet Air Oxidation, } \\
\text { BPA } & \text { : Bisphenol A, } \\
\text { EDC } & \text { : Endocrine Disrupting Chemical } \\
\text { AOPs } & : \text { Advanced Oxidation Processes, } \\
\text { XRD } & : \text { X-Ray Diffraction, } \\
\text { H2-TPR } & : \text { Temperature-Programmed Reduction, } \\
\text { ICP-OES } & : \text { Inductively Coupled Plasma Optical Emission Spectroscopy, } \\
\text { TEM } & : \text { Transmission Electron Microscopy, } \\
\text { TOC } & : \text { Total Organic Carbon, } \\
\text { COD } & : \text { Chemical Oxygen Demand, } \\
\text { HPLC } & : \text { High Performance Liquid Chromatography, } \\
\text { PFO } & : \text { Pseudo-First-Order. }
\end{array}
$$




\section{Introduction}

Bisphenol A (BPA) is a synthetic organic compound with two unsaturated phenolic rings attached by a bridging carbon. BPA is classified as an endocrine-disrupting chemical (EDC) with estrogenic properties, but it is still widely used as a plasticizer in the synthesis of polycarbonate plastics and epoxy resins (Ben-Jonathan and Steinmetz, 1998) because it is very durable; heat and shatter resistant, and can also improve the clarity of plastics. It is widely used in the manufacture of some food and beverage packaging, e.g., water and baby bottles, compact discs, dental sealants, medical devices and lacquers for coating metal products such as plastic cans, bottle caps and water pipes (Chapin et al., 2008; Chouhan et al., 2014). Thus, humans ingest BPA on an almost daily basis. It is known that babies and children are more affected by BPA than adults. BPA has been detected in urine and serum of pregnant women and in placental tissue, amniotic fluid and urine of babies (Vandenberg et al., 2007) In addition, BPA has also been detected in wastewater, groundwater, surface water and even drinking water (Lane et al., 2015; Lee et al., 2015; Zbair et al., 2018). Recent studies have indicated that the estrogenic activity of BPA at levels as low as $0.2 \mathrm{pg} / \mathrm{mL}$ causes endocrine disruption leading in infertility, breast cancer and thyroid cancer (Gültekin and Ince, 2007). There is therefore an urgent need to develop effective technology to remove BPA from wastewater and drinking water.

Up to date, a number of methods such as adsorption, biological treatment and advanced oxidation have been investigated to remove BPA from water (Anastopoulos et al., 2017; Mohapatra et al., 2010; Zbair et al., 2018). Biological treatment would be the least expensive, but it takes longer to remove BPA (Lobos et al., 1992; Omoike et al., 2013). Moreover, conventional biological management appears to have a low and unstable BPA removal capacity due to its very low concentration in water and high biorefractory properties (Cleveland et al., 2014; Staples et al., 1998). The adsorption process is simple and efficient, but it requires high operating costs related to the regeneration of spent adsorbents from contaminants (Cleveland et al., 2014). On the other hand, advanced oxidation processes (AOPs) have demonstrated a great capacity to degrade persistent organic matter through the formation of highly active oxidizing free radicals ( $\mathrm{HO}$ and $\mathrm{SO}_{4}{ }^{-}$) (Athalathil et al., 2015; Reddy and Kim, 2015). Among the processes of AOPs tested for the elimination of BPA, it can be mentioned: $\mathrm{UV} / \mathrm{H}_{2} \mathrm{O}_{2}$ process (Moussavi et al., 2018), electrogenerated ferrous ion activated ozone, $\mathrm{H}_{2} \mathrm{O}_{2}$ and persulfate system(Akbari et al., 2016), Fenton like process (Ahmadi et al., 2016; Arampatzidou et al., 2018) and catalytic wet air oxidation (CWAO) method (Erjavec et al., 2013). CWAO is a particularly effective and promising process for removing organic compounds, such as phenolic compounds, from wastewater (Keav et al., 2014; 
Nousir et al., 2008). Moreover, CWAO is an industrially feasible and environmentally-friendly system that destroys organic contaminants as biodegradable intermediates or mineralizes them into $\mathrm{CO}_{2}, \mathrm{H}_{2} \mathrm{O}$ and harmless end-products at high temperature $\left(125-320^{\circ} \mathrm{C}\right)$ and under oxygen or air pressure (0.5-20 MPa). Noble metals supported on oxides or carbon materials are widely studied in CWAO because of their high catalytic performance and resistance to metal leaching (Kim and Ihm, 2011; Levec and Pintar, 2007). However, the high cost and scarcity of these precious metals make it necessary to explore new routes to either minimize their use or replace them with non-noble catalysts with similar catalytic properties. For example, a titanium nanotube catalyst proved to be very effective for the destruction of BPA by CWAO. It showed a high activity of about $91 \%$ and a Total Organic Carbon (TOC) abatement of 69\% (Kaplan et al., 2014a), with the end products being mostly biodegradable compounds. In addition, $\mathrm{CeO}_{2}$ and $\mathrm{Ce}_{0.85} \mathrm{Zr}_{0.15} \mathrm{O}_{2}$ catalysts achieved 76\% BPA conversion and 75\% and 73\% TOC abatement, respectively (Heponiemi et al., 2015).

Phosphate-based materials have been of great interest in recent years as they can be used as fertilizers, catalysts, ion conductors, piezoelectric materials, biotechnological materials and sorbents. Currently, there is more interest in the use of these materials as catalysts for various chemical transformations. The novelty of this research is the investigation of inexpensive IronNickel-Phosphate oxide based catalysts in the catalytic wet air oxidation of an aqueous solution of Bisphenol A. The activity of the catalyst (Fe/NiP) and its stability were studied for the removal of Bisphenol A (BPA) by catalytic wet air oxidation (CWAO). The objective is to identify the features of the catalyst that will influence the activity and selectivity of the reaction.

\section{Materials and methods}

2.1.Preparation of nickel phosphate support (NiP)

The support was prepared by co-precipitation method using the required stoichiometric amount of aqueous solutions of the precursor salts $\mathrm{Ni}\left(\mathrm{NO}_{3}\right)_{2} \cdot 6 \mathrm{H}_{2} \mathrm{O}$ (Sigma-Aldrich Chemical company, 99\% purity) and $\left(\mathrm{NH}_{4}\right)_{2} \mathrm{HPO}_{4}$ (Sigma-Aldrich chemical Company, 99\% purity). The $\mathrm{Ni}\left(\mathrm{NO}_{3}\right)_{2} \cdot 6 \mathrm{H}_{2} \mathrm{O}$ salt solution was added dropwise to the ammonium hydrogenophosphate solution under continuous stirring. The $\mathrm{pH}$ was then adjusted to 9 with ammonia solution (25\%, Sigma-Aldrich chemical Company), the mixture was left under constant stirring for 3 hours. The obtained co-precipitate solution was dried overnight at $120^{\circ} \mathrm{C}$ and calcined under air flow at $450^{\circ} \mathrm{C}$ for 8 hours with a temperature rise of $5^{\circ} \mathrm{C} \mathrm{min}^{-1}$. The resulting support was labeled $\mathrm{NiP}$. 
126 The wet-impregnation method was used to deposit $20 \mathrm{wt}-\%$ of iron from an aqueous solution of $127 \mathrm{FeSO}_{4}, 7 \mathrm{H}_{2} \mathrm{O}$ (Sigma-Aldrich, 99\%). The support was brought into contact with the necessary 128 volume of iron solution. The mixture of Fe precursor solution and the support was stirred overnight 129 and dried at $60^{\circ} \mathrm{C}$ until the excess water evaporated completely. Finally, the dried sample was 130 calcined in an air atmosphere for 3 hours at $450^{\circ} \mathrm{C}$ with a ramp of $5^{\circ} \mathrm{C} \mathrm{min}^{-1}$.

\subsection{Characterization methods}

The X-ray diffraction (XRD) analysis of NiP and Fe/NiP was performed using a Bruker-BINARY, model D8 Diffractometer, equipped with a $\mathrm{Cu} \mathrm{K \alpha}$ radiation $\left(\lambda \mathrm{k}_{\alpha}=1.5418 \AA\right)$. Both samples were scanned in the range $2 \theta$ from 15 to $70^{\circ}$ with a $0.02^{\circ}$ step in $30 \mathrm{~s}$.

The specific surface areas, pore volume and pore size distribution of $\mathrm{NiP}$ and $\mathrm{Fe} / \mathrm{NiP}$ were measured by nitrogen physisorption at $-196^{\circ} \mathrm{C}$ using a Micrometrics TRISTAR 3000 device applying successively the BET and the BJH models. Prior to these measurements, the samples were degassed under vacuum at $250^{\circ} \mathrm{C}$ overnight to clean the surface of the materials.

$\mathrm{H}_{2}$-TPR (temperature-programmed reduction) measurements were performed on an Autochem II 2920 with a $10 \% \mathrm{H}_{2} / \mathrm{Ar}$ gas mixture and a flow rate set at $50 \mathrm{~mL} / \mathrm{min}$. Prior to the measurements, the samples were pretreated under Ar at $450^{\circ} \mathrm{C}$ for $1 \mathrm{~h}$, with a temperature ramp of $10^{\circ} \mathrm{C} / \mathrm{min}$, and then cooled down to room temperature. $\mathrm{H}_{2}$-TPR analysis was performed from room temperature to $850^{\circ} \mathrm{C}$ with a ramp of $10^{\circ} \mathrm{C} \mathrm{min}^{-1}$.

The Fe content of the prepared catalyst $(\mathrm{Fe} / \mathrm{NiP})$ was determined by inductively coupled plasma optical emission spectroscopy (ICP-OES). The analysis was performed using a Perkin-Elmer Optima 2000DV. Prior to analysis, a known mass of sample powder was dissolved in acid under microwave heating. The ICP analysis was also used to analyze the leaching of iron in aqueous solution after CWAO reaction.

The surface morphology of $\mathrm{NiP}$ and $\mathrm{Fe} / \mathrm{NiP}$ were observed by transmission electron microscopy using a "TEM / STEM JEOL 2100 UHR", with a resolution of $0.19 \mathrm{~nm}$, equipped with an EDAX energy dispersive spectrometer, a HAADF wide angle annular dark field detector and Gatan CCD camera.

\subsection{Catalytic experiments}

CWAO experiments were investigated in a $0.44 \mathrm{~L}$ batch reactor made of Hastelloy C22 alloy loaded with $160 \mathrm{~mL}$ of BPA solution $(0.3 \mathrm{~g} / \mathrm{L})$ and $\mathrm{NiP}$ or Fe/NiP catalyst $(4 \mathrm{~g} / \mathrm{L})$. After a purge with helium, the reactor was heated up to the reaction temperature. The stirring speed was set at 1000 
rpm. At the initial time of the reaction, 25 bars of pure $\mathrm{O}_{2}$ were introduced into the reactor. The pressure was kept constant during the experiment by regular refilling with $\mathrm{O}_{2}$. Samples of the liquid phase were periodically collected and filtered through a Durapore membrane $(0.45 \mu \mathrm{m} ; \varnothing=13 \mathrm{~mm})$ to remove all catalyst residues for analysis. The liquid samples were analyzed by HPLC using a 250 $\times 4.6 \mathrm{~mm}$ C18 reversed-phase column (Shimadzu Prominence UFLC $_{\mathrm{XR}}$ ). The mobile phase was a mix of 60 vol. $\%$ methanol and 40 vol. \% water (flow rate: $0.8 \mathrm{~mL} / \mathrm{min}$ ). The HPLC system was equipped with a UV-visible detector fixed at $276 \mathrm{~nm}$. Total Organic Carbon (TOC) values were determined using a total organic analyzer Shimadzu LCPH/CPN. The HPLC and TOC devices are calibrated using standard solutions of Bisphenol A in ultra-pure water. At the end of the CWAO reaction $(180 \mathrm{~min})$, the reactor was cooled down to room temperature. ICP analysis of the remaining solutions was performed to ensure that iron did not leach from the Fe/NiP catalyst. It is worth noted that the reproducibility of the experimental protocol was proved for several reference catalysts and that the experimental error was found to be less than $5 \%$.

\section{Results and Discussion}

\subsection{Characterization of samples}

X-ray diffraction was used to identify crystalline phases formed in NiP support and Fe/NiP catalyst. Fig. 1a shows the XRD patterns of NiP and Fe/NiP samples which display amorphous phases and semi-crystalline peaks. By comparison with ICDD database (International Centre for Diffraction Data), it appears that the main crystalline phase on the NiP support is a monoclinic structure of $\mathrm{Ni}_{3}\left(\mathrm{PO}_{4}\right)_{2}$ (ICDD: 00-038-1473). As expected, the XRD pattern of Fe/NiP catalyst reveals the presence of $\mathrm{Ni}_{3}\left(\mathrm{PO}_{4}\right)_{2}$ phase. It presents also a hydrated phase of iron sulfate hydroxide $\left(\left(\mathrm{Fe}_{1.33}^{2+} \mathrm{Fe}_{0.67}^{3+}\left(\mathrm{SO}_{4}\right)_{2}(\mathrm{OH})_{0.67} \cdot \mathrm{xH}_{2} \mathrm{O}\right)\right.$ (ICDD: 00-053-1056), as well as unidentified phases. The amount of iron impregnated on NiP support, determined by ICP analysis, is 18.5 wt-\% (Table 1), which is close to the target value (20 wt- $\%)$.

According to IUPAC Classification (Sing, 1985), the $\mathrm{N}_{2}$-physorptions on NiP and Fe/NiP evidence type IV isotherms indicating the presence of mesopores (Fig. 1b). Both isotherms exhibit type H3 hysteresis loop, indicating the presence of non-rigid aggregates of plate-like particles or assemblages of slit-like pores.

For comparison purposes, the specific surface area, the total pore volume, and the average pore diameter obtained from nitrogen physisorption isotherms of $\mathrm{NiP}$ and $\mathrm{Fe} / \mathrm{NiP}$ are summarized in Table 1. All the textural parameters decrease after the impregnation of iron, suggesting that iron particles partially block NiP support pores. 

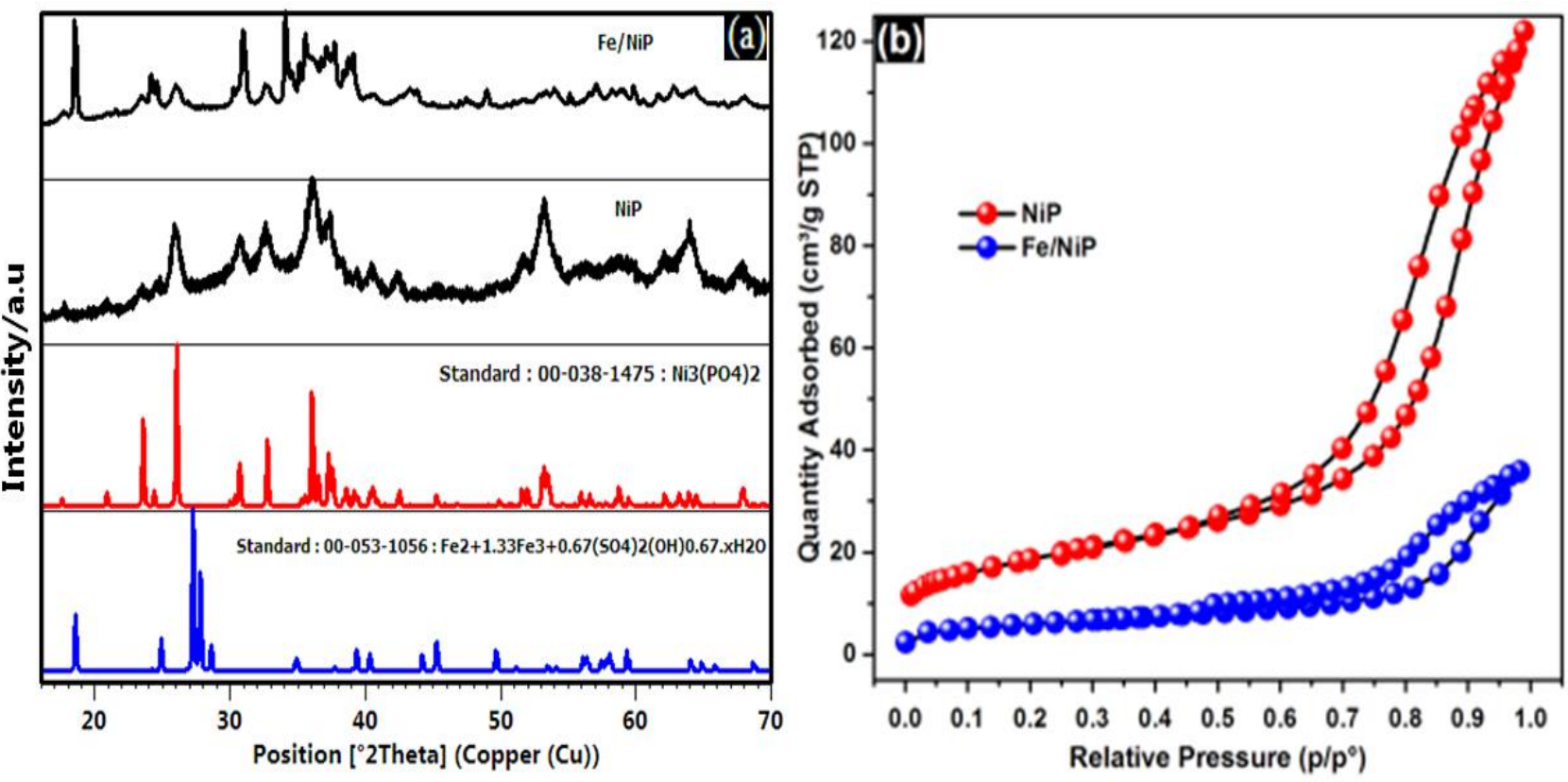

Fig. 1: XRD patterns (a) and Nitrogen adsorption-desorption isotherms (b) of $\mathrm{NiP}$ and $\mathrm{Fe} / \mathrm{NiP}$.

Table 1. Textural parameters and ICP analysis of NiP and Fe/NiP.

\begin{tabular}{ccccc}
\hline Sample & $\begin{array}{c}\text { SBET } \\
\left(\mathbf{m}^{2} / \mathbf{g}\right)\end{array}$ & $\begin{array}{c}\text { Total pore } \\
\text { volume }\left(\mathbf{c m}^{3} / \mathbf{g}\right)\end{array}$ & $\begin{array}{c}\text { Average pore diameter } \\
(\mathbf{n m})\end{array}$ & $\begin{array}{c}\text { Fe Content } \\
(\mathbf{w t}-\mathbf{\%})\end{array}$ \\
\hline NiP & 66 & 0.18 & 10.8 & - \\
\hline Fe/NiP & 21 & 0.05 & 9.2 & 18.5 \\
\hline
\end{tabular}

$\mathrm{H}_{2}$-Temperature Programmed Reduction $\left(\mathrm{H}_{2}\right.$-TPR) was performed on the samples. Fig. 2 shows the hydrogen uptakes as a function of temperature, obtained for NiP (Fig. 2a) and Fe/NiP (Fig. 2b). The decomposition of the TPR profile of NiP reveals several peaks located around 407, 444, 543, $645,725,781$, and $820^{\circ} \mathrm{C}$ (Fig. 2a). According to the literature, the peaks at $407^{\circ} \mathrm{C}$ and $444^{\circ} \mathrm{C}$ can be attributed to the reduction of small and large crystallites of $\mathrm{NiO}$ to $\mathrm{Ni}$ metallic, respectively (Bui et al., 2012; Chen et al., 2014; Pan et al., 2016; Zou et al., 2018). The peak at $543^{\circ} \mathrm{C}$ is related to the phosphidation of nickel (Bui et al., 2012). Furthermore, the peak at $645^{\circ} \mathrm{C}$ can be assigned to the reduction of nickel oxy-phosphate (Chen et al. 2014). In addition, the peaks at 725,781 , and $820^{\circ} \mathrm{C}$ could be due to the reduction of nickel oxy-phosphate, nickel phosphate and P-O bond (Bui et al., 2012; Chen et al., 2014; Pan et al., 2016).

Fig. $2 \mathbf{b}$ shows that the addition of iron to NiP strongly modifies the shape of the TPR profile of NiP (Fig. 2a). Decomposed TPR curve of Fe/NiP displays four peaks at $460,482,524$ and $770^{\circ} \mathrm{C}$. The reduction temperature of $\mathrm{NiO}$ to metallic $\mathrm{Ni}$ shifts slightly to a higher temperature in the presence of 
206 is explained by an interaction between $\mathrm{Ni}$ and $\mathrm{Fe}$. The peak at $482^{\circ} \mathrm{C}$ can be assigned to the 207 reduction of $\mathrm{Fe}_{2} \mathrm{O}_{3}$ to $\mathrm{Fe}_{3} \mathrm{O}_{4}$ (Chen et al., 2014; Pan et al., 2016) and the peak at $524^{\circ} \mathrm{C}$ can be 208 attributed to the co-reduction of $\mathrm{Fe}_{2} \mathrm{O}_{3}$ and $\mathrm{Fe}_{3} \mathrm{O}_{4}$ to $\mathrm{FeO}$ and $\mathrm{Fe}$ (Zhang et al., 2018; Zou et al., 209 2018). Finally, the peak at $770^{\circ} \mathrm{C}$ can be due to the reduction of iron-phosphate (Chen et al., 2014) 210 or the co-reduction of nickel and iron associated with phosphate (Pan et al., 2016).
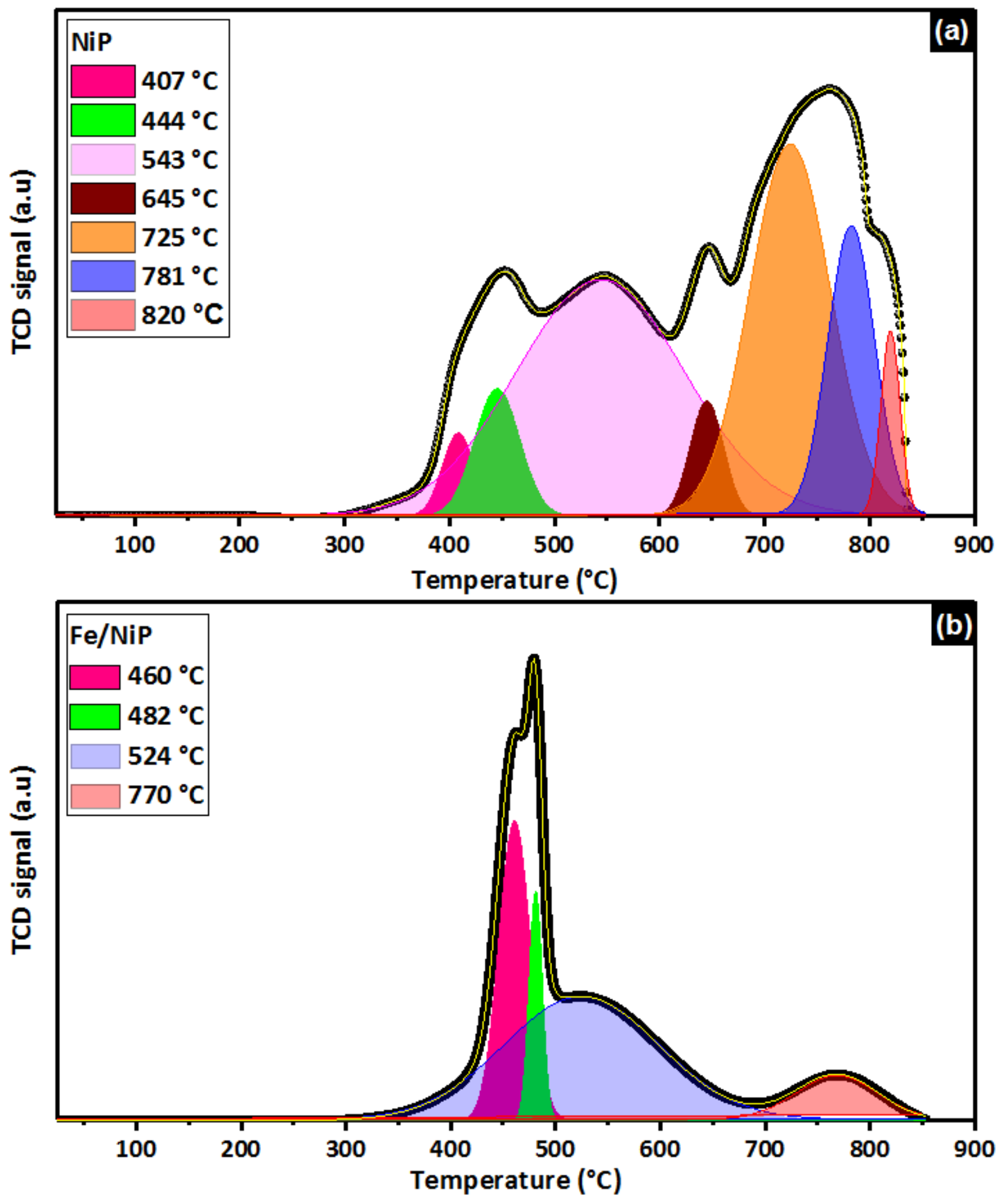
213 The Transmission Electron Microscopy (TEM) images of NiP and Fe/NiP are shown in Fig.3.

214 As it can be seen in Fig. 3a and 3b, NiP exhibits an amorphous nano-cylindrical morphology with 215 different thicknesses ranging from 13 to $49 \mathrm{~nm}$. In addition, the TEM images also indicate the 216 presence of interconnected mesopores. The distribution of particle size is centered at $5.5 \mathrm{~nm}$ (Fig. 217 3c). In contrast, after the impregnation of Fe on NiP, the nano-cylindrical morphology and the 218 porosity are not observed (Fig. 3d), this can be explained by the high dispersion of Fe (yellow 219 color) on the surface of NiP. Indeed, the map analysis of the Fe/NiP sample (Fig. 3e) shows the 220 homogenous distribution of Fe on the NiP surface. Furthermore, the mapping analysis reveals the 221 presence of sulfur (green color), which is present in the active phase $222\left(\left(\mathrm{Fe}_{1.33}^{2+} \mathrm{Fe}_{0.67}^{3+}\left(\mathrm{SO}_{4}\right)_{2}(\mathrm{OH})_{0.67} \cdot \mathrm{XH}_{2} \mathrm{O}\right)\right)$, already identified by XRD. This result is therefore in good 223 agreement with $\mathrm{N}_{2}$-physisorption analysis, which reveals a decrease in surface area due to the 224 clogging of pores by Fe particles. 

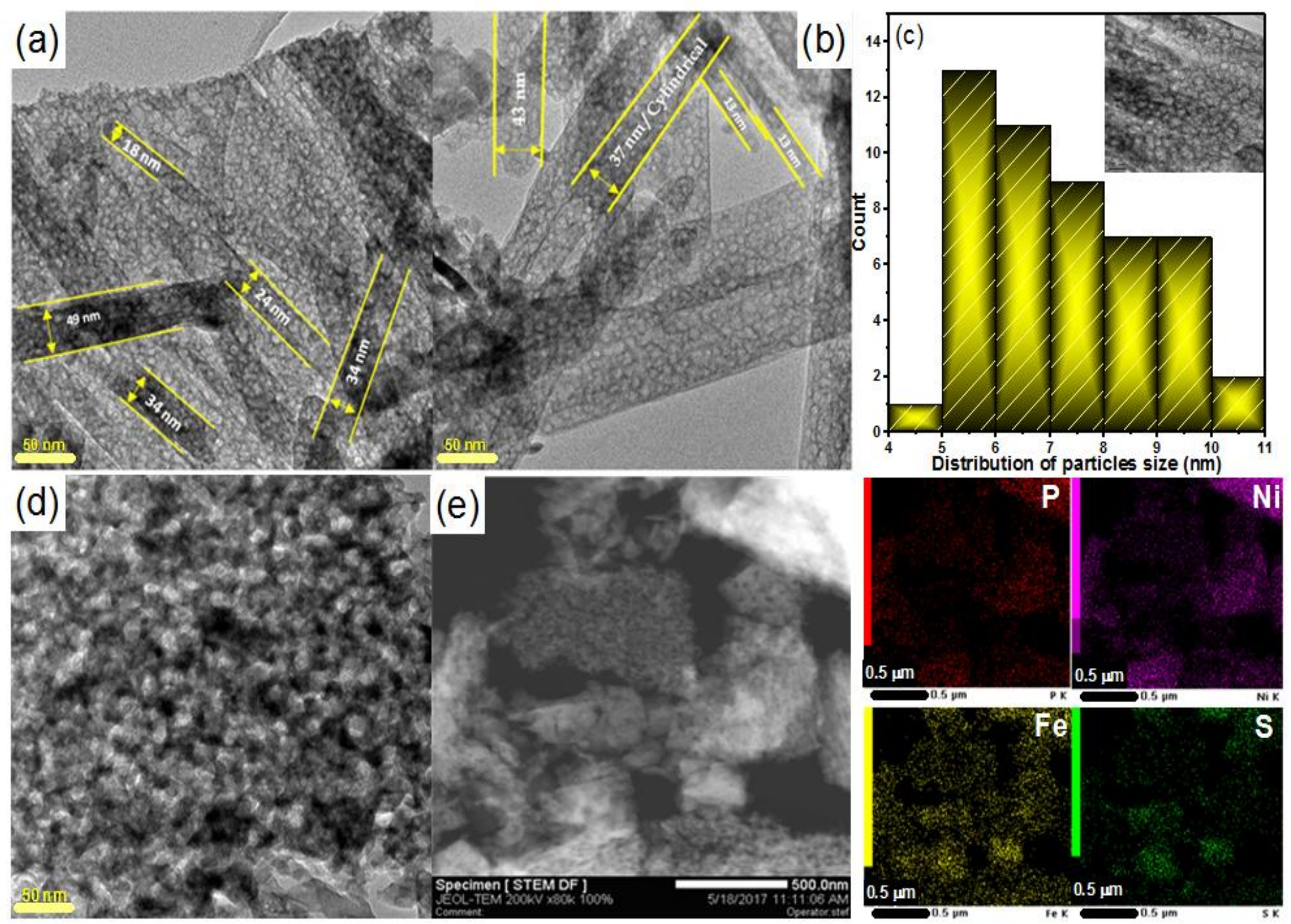

Fig. 3 (a) and (b): TEM images of NiP, (c): Distribution of particle size, (d): TEM of Fe/NiP, and (e): TEM-mapping. 


\subsection{Catalytic results}

\subsubsection{Thermal decomposition (blank tests)}

The temperature plays a very important role in the WAO process of degradation of hazardous organic pollutants. Thus, the rate of reaction, the total reduction of TOC and COD are highly dependent on the temperature (Kaplan et al., 2014b; Pintar et al., 2008). Moreover, the mechanism of degradation of organic pollutants in the WAO process is also strongly related to the reaction temperature due to the various types of free radicals that can be generated (Pintar et al., 2008). For this reason, blank experiments i.e without a catalyst, were carried out to study the thermal decomposition of BPA at $140^{\circ} \mathrm{C}$. Fig. 4a displays BPA conversion as a function of time. Blank test shows that the conversion of BPA after $180 \mathrm{~min}$ at $140^{\circ} \mathrm{C}$ reaches only $37.0 \%$ and leads to many by-products, as shown on the HPLC chromatogram displayed in Fig. 4b. This result is explained by the fact that the aromatic structure of the phenolic compounds gives them a high activation energy for WAO. Consequently, higher reaction temperature is required to get over such high activation energy barriers (Mirzaee et al., 2018). In order to avoid excessive temperature conditions and thus reduce the cost, the use of a catalyst is necessary to improve the conversion of BPA and to avoid the formation of by-products.
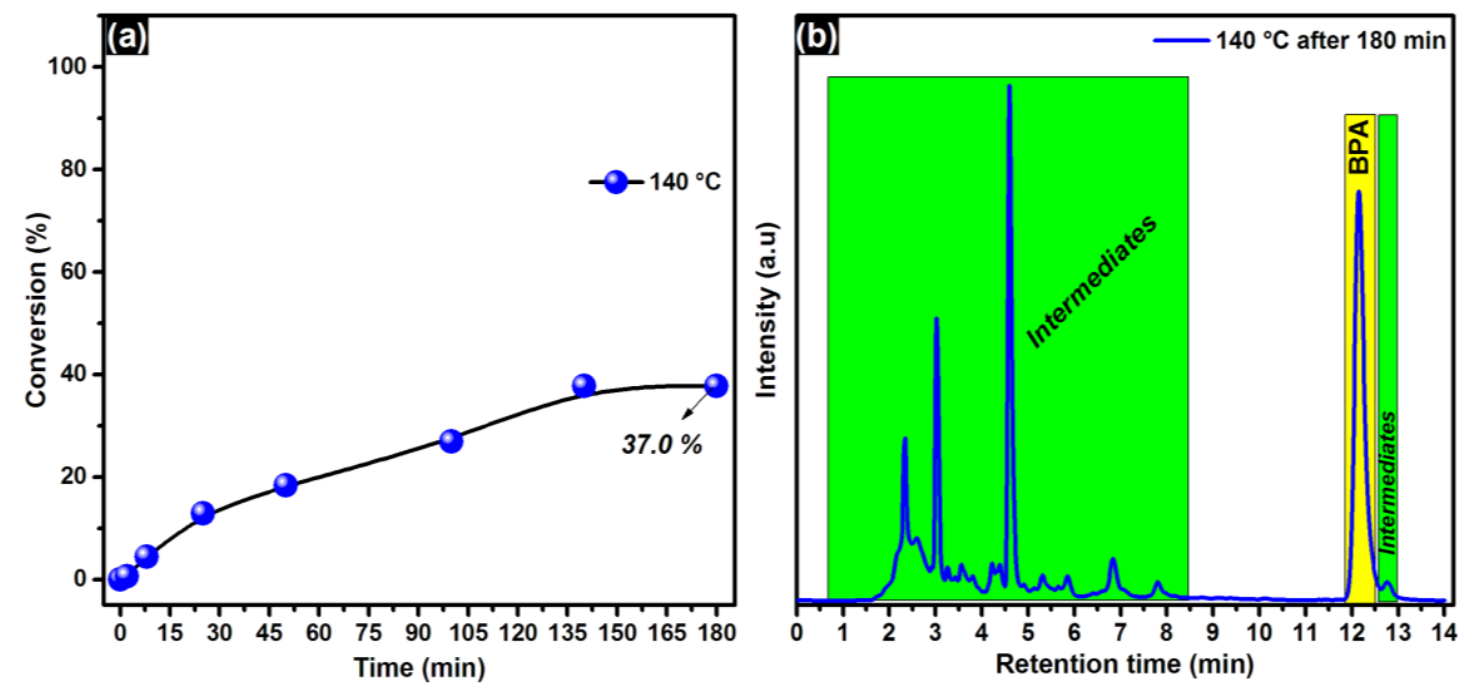

Fig. 4 (a) Thermal decomposition of BPA at $140{ }^{\circ} \mathrm{C}$ (b) HPLC chromatogram for WAO of BPA (without catalyst).

\subsubsection{Effect of support and catalyst}

First, the NiP support was tested to evaluate its performance for CWAO of BPA. Fig. 5a shows that BPA conversion after $180 \mathrm{~min}$ of reaction (37\%) is similar to that obtained with the blank test at $140^{\circ} \mathrm{C}$. On the other hand, the modification of NiP by Fe induces a significant increase in catalytic 
properties. Fe/NiP exhibits a good catalytic activity since the BPA is fully converted (99.8\%) after 180 min of reaction (Fig. 5a) and $85 \% \Delta$ TOC are achieved (Table 2) versus only $35 \%$ with NiP. Nevertheless, BPA was not entirely transformed into carbon dioxide, which implies the formation of some organic intermediates.

Liquid phase samples were periodically collected during the CWAO process for analysis by HPLC for the blank test, NiP and Fe/NiP. The conversion curves are displayed in Fig. 5a. The HPLC chromatograms focused on the BPA peaks were illustrated in Fig. 5b, c and d. The inset figures (Fig. 5b, c and d) showed the temporal evolution of the spectral changes of BPA generated by HPLC of BPA conversion using NiP and Fe/NiP samples. With the reaction time, the peak intensity of BPA gradually decreases. BPA is fully converted after $180 \mathrm{~min}$ for Fe/NiP. The disappearance of BPA is accompanied by the formation of its by-products similarly to that is observed in Fig. 4b. The formation of these by-products is in accordance with the values of $\triangle \mathrm{TOC}$.

Comparison of the HPLC chromatograms (Fig. 6a, b) after $180 \mathrm{~min}$ of reaction shows that several intermediates are detected in the case of $\mathrm{NiP}$ while only two peaks are detected in the case of $\mathrm{Fe} / \mathrm{NiP}$. These peaks are detected at a shorter retention time than that of BPA, indicating that the intermediates produced are more polar than BPA. This is in agreement with the results stated in the preview study on the degradation of BPA (Tai et al., 2005). However, all detected peak areas of the BPA intermediates were much lower than those of the initial BPA. In other words, fluctuations of these BPA intermediates as a function of time reveal different possible step in the degradation pathways of BPA, and it is, therefore, difficult to identify them. Although the study does not aim to analyze in detail the by-products obtained during the CWAO of BPA, the main products detected were tentatively identified in comparison to the studies of Miho Sasaki et al (Sasaki et al., 2005b, 2005a), Vincent Cleveland et al (Cleveland et al., 2014) and Buddhika Rathnayake et al (Rathnayake et al., 2019). Thus, the HPLC analysis (Fig. 6c) of BPA solution treated by CWAO using $\mathrm{Fe} / \mathrm{NiP}$ at $140^{\circ} \mathrm{C}$ after $180 \mathrm{~min}$ revealed the formation of two intermediates: 4'hydroxyacetophenone and 1,2-bis(4-hydroxyphenyl)-2-propanol. 

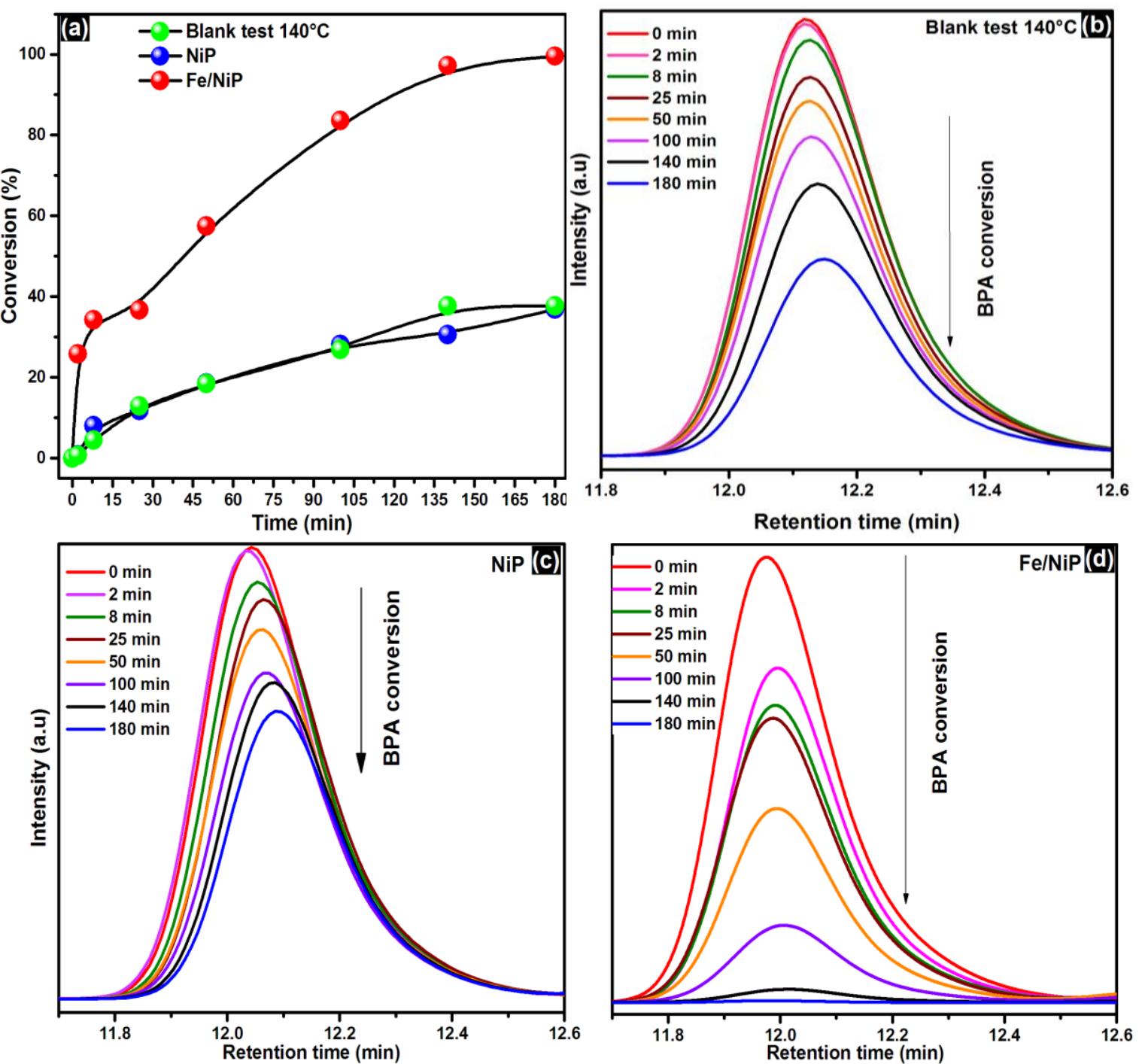

Fig. 5: (a) Kinetics of BPA conversion (\%), (b) HPLC chromatograms focused on BPA without catalyst at $140^{\circ} \mathrm{C}$ (c) using NiP, (d) using Fe/NiP.

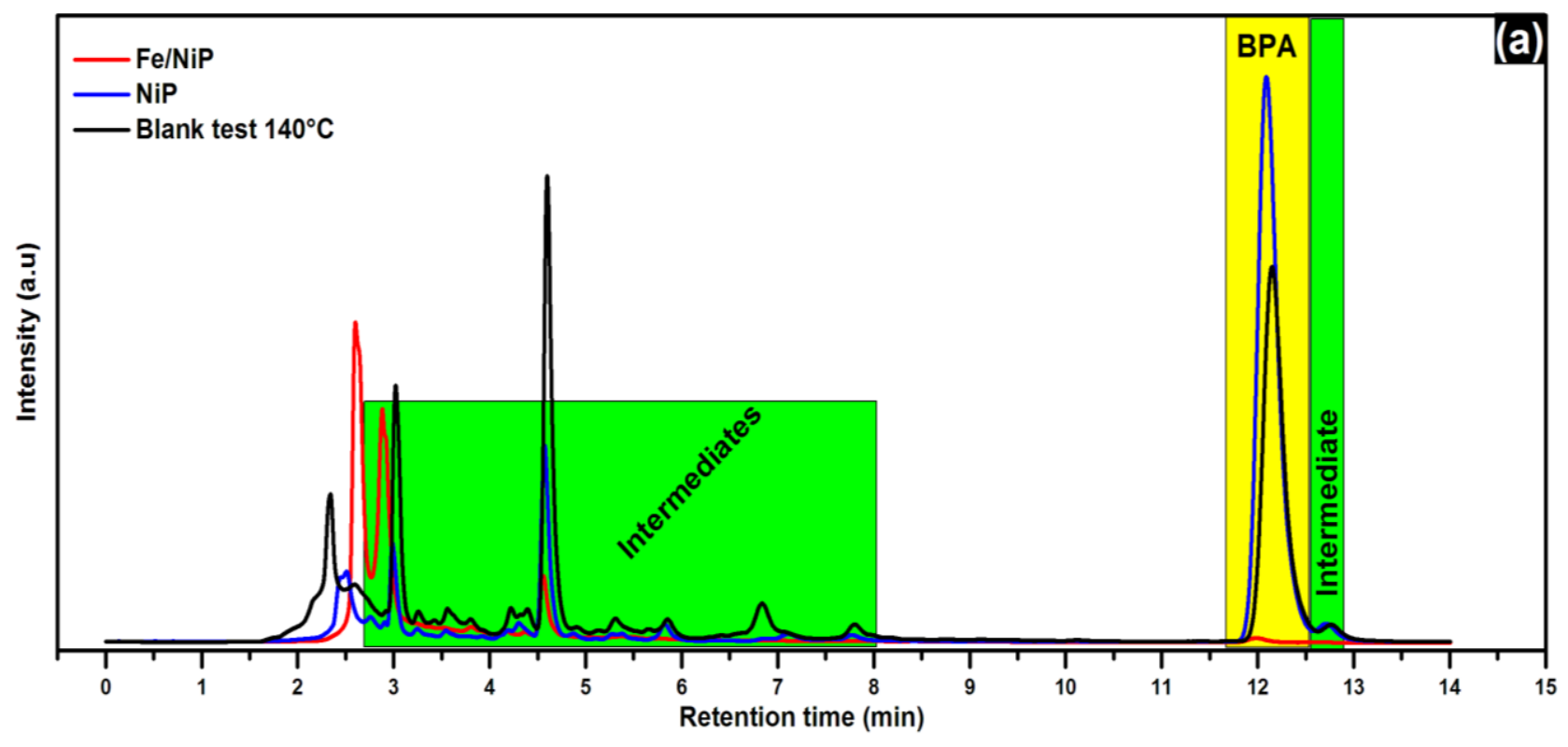



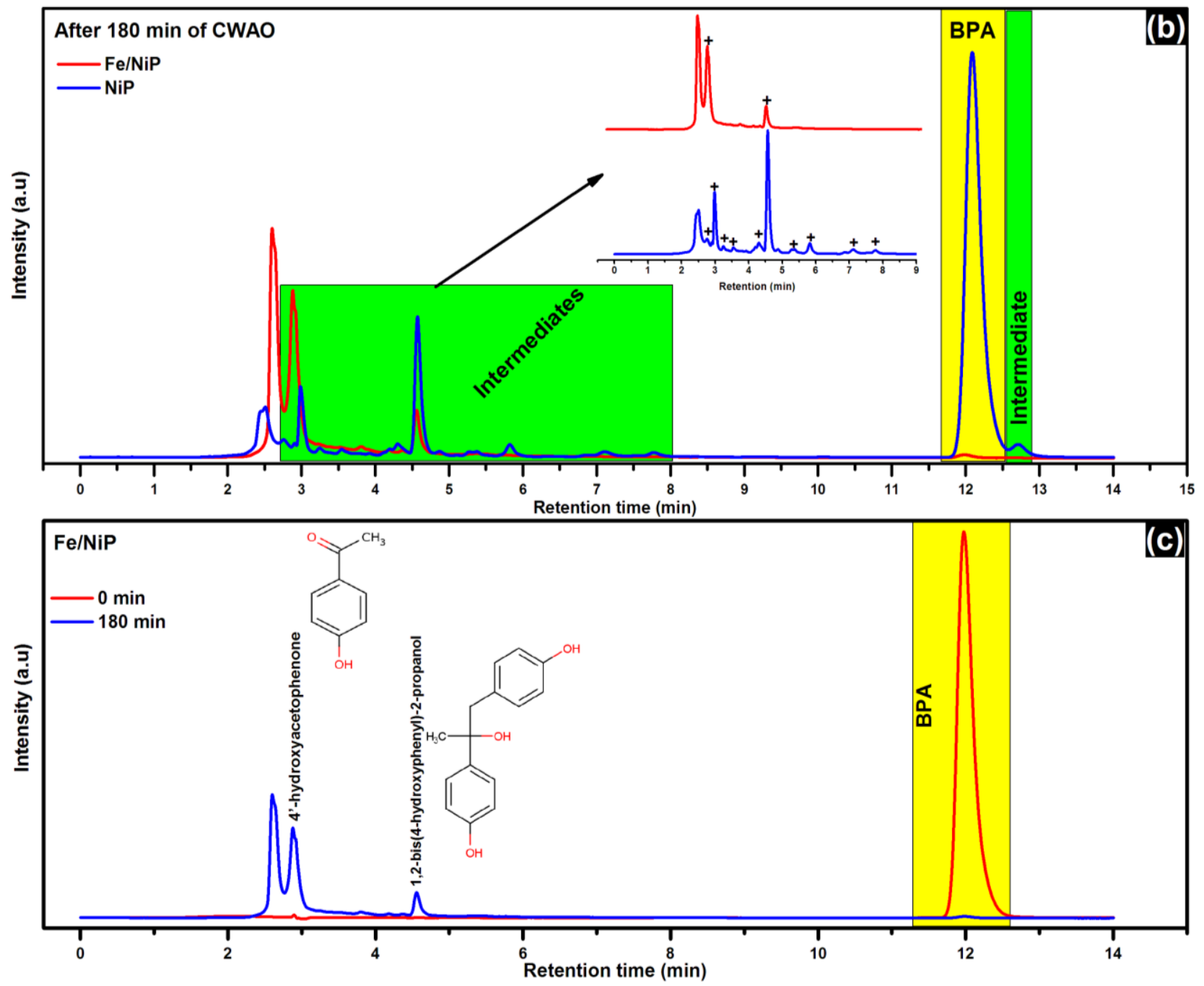

Fig.6: Intermediates detection by HPLC analysis during CWAO of BPA: (a) comparison between the blank test at $140^{\circ} \mathrm{C}$, NiP and $\mathrm{Fe} / \mathrm{NiP}$ after 180 min of reaction, (b) comparison between $\mathrm{NiP}$ and $\mathrm{Fe} / \mathrm{NiP}$ after $180 \mathrm{~min}$ of reaction, (c) comparison after 0 and $180 \mathrm{~min}$ reaction time for $\mathrm{Fe} / \mathrm{NiP}$.

\subsubsection{Kinetic modeling of CWAO reaction of BPA}

The kinetics of BPA CWAO reaction was modeled according to the pseudo-first-order (PFO) ratelaw. The measured data were fitted by using a non-linear model, according to the following equation (Equ.1):

$$
C(t)=C_{t o t}\left(1-e^{-k t}\right)
$$

Equ.1

Where the total conversion $\left(\mathrm{C}_{\text {tot }}\right)$ and the rate constant $(k)$ were used as fitting parameters. The term " $\mathrm{t}$ " was the CWAO reaction time. The calculated $\mathrm{R}^{2}$ values and the residual analysis were used as parameters to evaluate the quality of the fit. Fig. 7 displays both the experimental and fitted BPA conversion as a function of reaction time for $\mathrm{NiP}$ and Fe/NiP. The possible rate constants for NiP and $\mathrm{Fe} / \mathrm{NiP}$ would be 0.014 and $0.020 \mathrm{~min}^{-1}$, respectively. Therefore, the addition of iron to NiP clearly enhanced the conversion of BPA and the rate of reaction. 


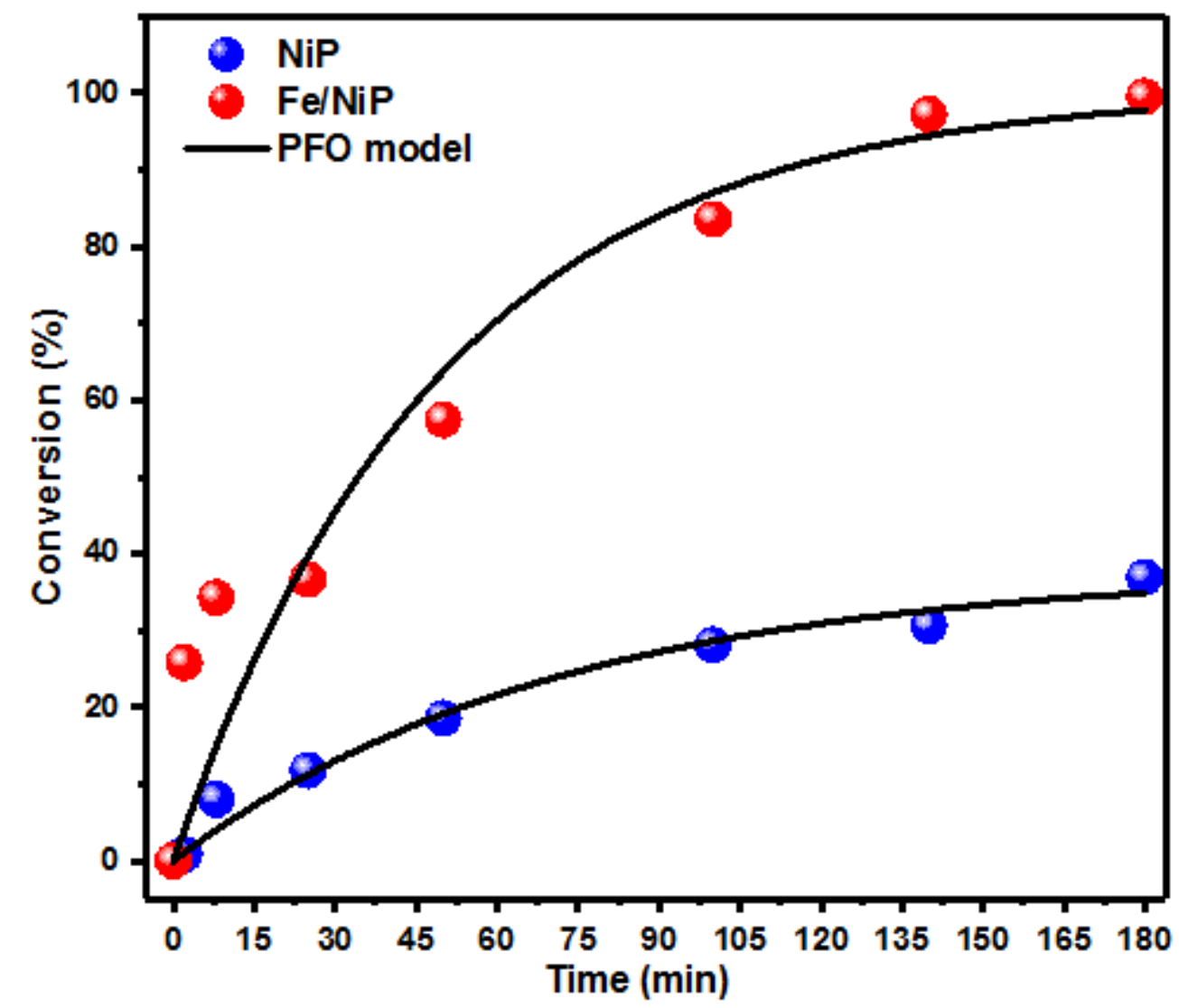

Fig. 7 Pseudo-first-order kinetic fitting of BPA conversion for $\mathrm{NiP}$ and $\mathrm{Fe} / \mathrm{NiP}$.

298 In addition to being efficient for the CWAO reaction, the catalyst must be stable under the operating 299 conditions. To evaluate the stability of the Fe/NiP catalyst, it was reused three times in consecutive 300 CWAO reactions. Once the catalyst was removed from the autoclave, it was filtered, washed with 301 ultrapure water and then dried in the oven at $60^{\circ} \mathrm{C}$.

302 Fig. 8 shows that the BPA conversion remains at about $99 \%$ after 3 cycles. However, the efficiency 303 of the solid declines over the multiple cycles since the $\% \Delta$ TOC decreases which could be due to 304 the accumulation of intermediates and by-products onto Fe/NiP surface. Furthermore, the ICP 305 analysis of the remaining solution after each cycle shows negligible leaching of iron (Table 2), 306 indicating high stability of iron in the prepared catalyst (Fe/NiP). Nickel leaching is also negligible: $307860 \mathrm{ppm}(0.08 \mathrm{wt}-\%)$ after the first cycle and around 60-75 ppm for each subsequent cycles. 


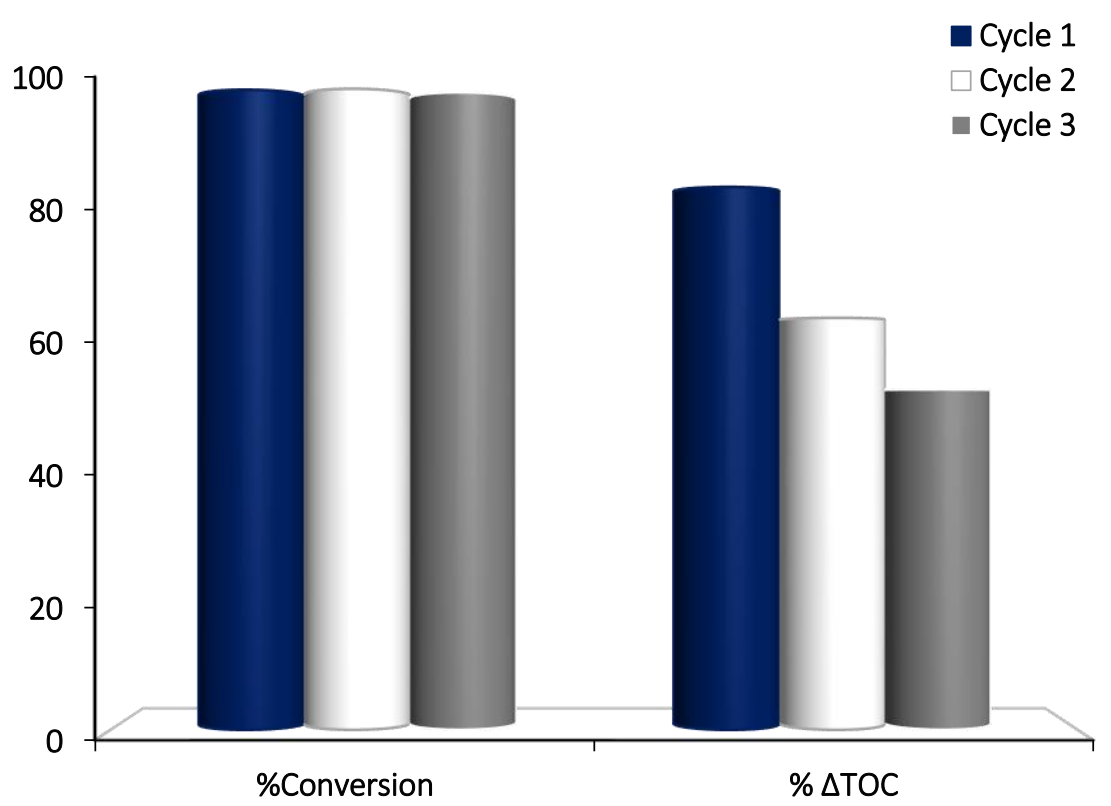

Fig. 8 Catalytic performance of $\mathrm{Fe} / \mathrm{NiP}$ reused three times in consecutive $\mathrm{CWAO}$ reactions. Conversion of BPA and TOC abatement $(\triangle \mathrm{TOC})$ after $180 \mathrm{~min}$ of reaction.

Table 2. Metal leaching after 180 min of CWAO of BPA using the catalyst Fe/NiP.

\begin{tabular}{llll}
\hline leaching & Cycle 1 & Cycle 2 & Cycle 3 \\
\hline$[\mathrm{Fe}](\mathbf{p p m})$ & 0.03 & 0.03 & 0.02 \\
\hline$[\mathrm{Ni}](\mathbf{p p m})$ & 859.50 & 60.80 & 74.80 \\
\hline
\end{tabular}

The diffractograms of the catalysts after each cycle (Fig. 9) reveal the disappearance of the $\mathrm{Fe}_{2}\left(\mathrm{SO}_{4}\right)_{2}(\mathrm{OH})_{0.67} \times \mathrm{H}_{2} \mathrm{O}$ (ICDD: 00-053-1056) phase and the appearance of a new $\mathrm{Fe}_{3}\left(\mathrm{PO}_{4}\right)_{2}(\mathrm{OH})_{2}$ (ICDD: 00-014-0569) phase. The $\mathrm{Ni}_{3}\left(\mathrm{PO}_{4}\right)_{2}$ (ICDD: 00-038-1473) phase is also present in either crystalline or amorphous form, which seems to promote the conversion of BPA. In order to verify the synergistic effect between the iron phase and the nickel phase, an FeP catalyst was prepared using the same method of preparation as for the NiP catalyst. This catalyst was than evaluated for the CWAO of BPA. The results obtained are summarized in Table 3. Although the FeP catalyst has a high conversion of BPA, very close to that of $\mathrm{Fe} / \mathrm{NiP}$, the presence of the nickel phase in $\mathrm{Fe} / \mathrm{NiP}$ results in a higher $\triangle \mathrm{TOC}$, around $85.0 \%$. It can be concluded that the iron phase enables almost total conversion of BPA, but the addition of nickel is necessary to promote total oxidation. 


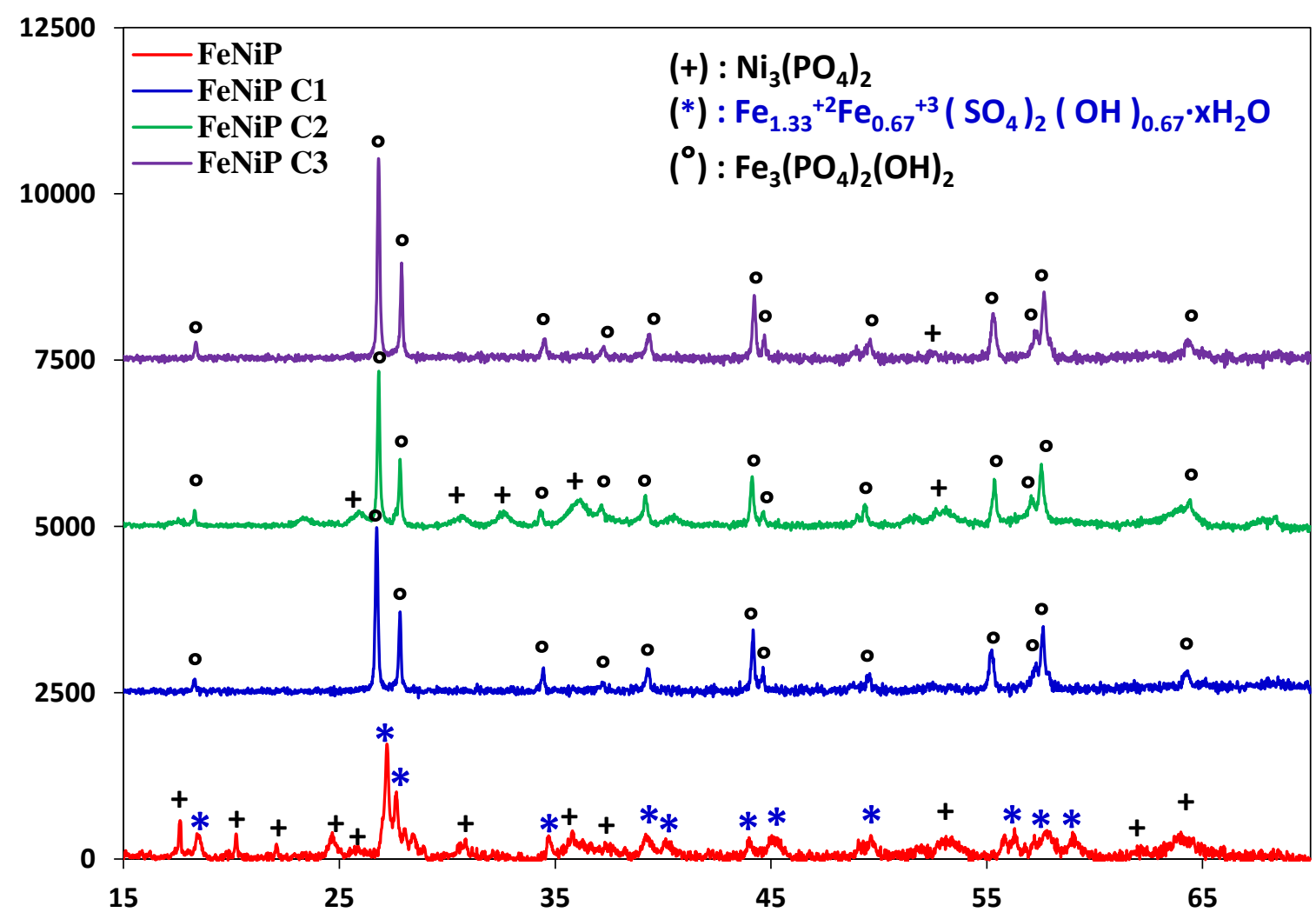

Fig. 9 XRD patterns of Fe/NiP after 180 min of CWAO of BPA for three cycles.

Table 3. Conversion of Bisphenol A and $\triangle T O C$ after 180 min at $140{ }^{\circ} \mathrm{C}$.

\begin{tabular}{ccc}
\hline Sample & BPA conversion $(\boldsymbol{\%})$ & \% \\
\hline NiP & 37.0 & 35.0 \\
\hline Fe/NiP & 99.6 & 85.0 \\
\hline FeP & 99.7 & 64.4 \\
\hline
\end{tabular}

3.2.5. Comparison of our results to other works

326 Table 4 provides a comparison of our results with those reported in the literature for the CWAO of 327 BPA. It appears that the Fe/NiP material has better catalytic performance, both in terms of 328 conversion and TOC abatement ( $\triangle \mathrm{TOC})$.

329 Table 4. Comparison of CWAO of BPA conversion and $\triangle T O C$ on different catalysts.

\begin{tabular}{lcccccc}
\hline Catalyst & $\begin{array}{c}\text { BPA initial } \\
\text { concentration } \\
(\mathbf{m g} / \mathbf{L})\end{array}$ & $\begin{array}{c}\text { Temperature } \\
\left({ }^{\circ} \mathbf{C}\right)\end{array}$ & $\begin{array}{c}\text { Time } \\
(\mathbf{m i n})\end{array}$ & $\begin{array}{c}\text { Conversion } \\
(\%)\end{array}$ & $\begin{array}{c}\% \\
\boldsymbol{\Delta} \mathbf{\%}) \mathrm{C}\end{array}$ & References \\
\hline $\mathbf{C e O}_{2}$ & 60 & 160 & 180 & 76 & 75 & $\begin{array}{l}\text { (Heponiemi } \\
\text { et al., 2015) }\end{array}$ \\
\hline $\mathbf{C e}_{0.85} \mathbf{Z r}_{\mathbf{0 . 1 5}} \mathbf{O}_{\mathbf{2}}$ & 60 & 160 & 180 & 76 & 73 & $\begin{array}{c}\text { (Heponiemi } \\
\text { et al., 2015) }\end{array}$ \\
\hline
\end{tabular}




\begin{tabular}{lcccccc}
\hline $\begin{array}{l}\text { Titanate } \\
\text { nanotube }\end{array}$ & 10 & 200 & $\begin{array}{c}\text { Several } \\
\text { hours }\end{array}$ & 91 & 69 & $\begin{array}{c}\text { (Kaplan et } \\
\text { al., 2014b) }\end{array}$ \\
\hline Ru/CNS & 20 & 130 & 90 & $>99$ & nd & $\begin{array}{c}\text { (Serra-Pérez } \\
\text { et al., 2019) }\end{array}$ \\
\hline $\mathbf{P t / 0 . 8 T i - 0 . 2 C e}$ & 60 & 160 & 180 & 72 & 48 & $\begin{array}{c}\text { (Rathnayake } \\
\text { et al., 2019) }\end{array}$ \\
\hline $\mathbf{F e} / \mathbf{N i P}$ & 300 & 140 & 180 & $>99$ & 85 & This work \\
\hline
\end{tabular}

\section{Conclusion}

The catalytic wet air oxidation of BPA was investigated by nickel phosphate as support (NiP) and iron supported on $\mathrm{NiP}$ as a catalyst. The conversion of BPA was studied at $140^{\circ} \mathrm{C}$ and 25 bar of total pressure. The CWAO reaction using $\mathrm{Fe} / \mathrm{NiP}$ catalyst was effective in achieving almost complete conversion of BPA in 180 min of reaction. Moreover, Fe/NiP catalyst showed rather high stability given the severe operating conditions (acidic media, high pressure, high temperature) and was still highly effective in successive runs. We also demonstrated that $\mathrm{FeP}$ and $\mathrm{Fe} / \mathrm{NiP}$ have high and similar activity, but the presence of the $\mathrm{Ni}$ phase $\left(\mathrm{Ni}_{3}\left(\mathrm{PO}_{4}\right)_{2}\right)$ leads to a higher $\Delta \mathrm{TOC}$.

Studies are still ongoing in order to provide further insight into the CWAO of BPA for possible practical application.

\section{Conflict of interest}

The authors declare no conflict of interest

\section{References}

Ahmadi, M., Rahmani, H., Takdastan, A., Jaafarzadeh, N., Mostoufi, A., 2016. A novel catalytic process for degradation of bisphenol A from aqueous solutions: A synergistic effect of nanoFe3O4@Alg-Fe on O3/H2O2. Process Saf. Environ. Prot. 104, 413-421. https://doi.org/10.1016/j.psep.2016.09.008

Akbari, S., Ghanbari, F., Moradi, M., 2016. Bisphenol A degradation in aqueous solutions by electrogenerated ferrous ion activated ozone, hydrogen peroxide and persulfate: Applying low current density for oxidation mechanism. Chem. Eng. J. 294, 298-307. https://doi.org/10.1016/j.cej.2016.02.106

Anastopoulos, I., Anagnostopoulos, V.A., Bhatnagar, A., Mitropoulos, A.C., Kyzas, G.Z., 2017. A review for chromium removal by carbon nanotubes. Chem. Ecol. 33, 572-588. https://doi.org/10.1080/02757540.2017.1328503 
Arampatzidou, A., Voutsa, D., Deliyanni, E., 2018. Removal of bisphenol A by Fe-impregnated activated carbons. Environ. Sci. Pollut. Res. Int. 25, 25869-25879. https://doi.org/10.1007/s11356-018-2652-4

Athalathil, S., Erjavec, B., Kaplan, R., Stüber, F., Bengoa, C., Font, J., Fortuny, A., Pintar, A., Fabregat, A., 2015. TiO2-sludge carbon enhanced catalytic oxidative reaction in environmental wastewaters applications. J. Hazard. Mater. 300, 406-414. https://doi.org/10.1016/j.jhazmat.2015.07.025

Ben-Jonathan, N., Steinmetz, R., 1998. Xenoestrogens: the emerging story of bisphenol a. Trends Endocrinol. Metab. TEM 9, 124-128. https://doi.org/10.1016/s1043-2760(98)00029-0

Bui, P., Cecilia, J.A., Oyama, S.Ted., Takagaki, A., Infantes-Molina, A., Zhao, H., Li, D., Rodríguez-Castellón, E., Jiménez López, A., 2012. Studies of the synthesis of transition metal phosphides and their activity in the hydrodeoxygenation of a biofuel model compound. J. Catal. 294, 184-198. https://doi.org/10.1016/j.jcat.2012.07.021

Chapin, R.E., Adams, J., Boekelheide, K., Gray, L.E., Hayward, S.W., Lees, P.S.J., McIntyre, B.S., Portier, K.M., Schnorr, T.M., Selevan, S.G., Vandenbergh, J.G., Woskie, S.R., 2008. NTPCERHR expert panel report on the reproductive and developmental toxicity of bisphenol A. Birth Defects Res. B. Dev. Reprod. Toxicol. 83, 157-395. https://doi.org/10.1002/bdrb.20147

Chen, J., Shi, H., Li, L., Li, K., 2014. Deoxygenation of methyl laurate as a model compound to hydrocarbons on transition metal phosphide catalysts. Appl. Catal. B Environ. 144, 870884. https://doi.org/10.1016/j.apcatb.2013.08.026

Chouhan, S., Prakash, J., Swati, Singh, S.P., 2014. Effect of Bisphenol A on human health and its degradation by microorganisms: a review. Ann. Microbiol. 64, 13-21. https://doi.org/10.1007/s13213-013-0649-2

Cleveland, V., Bingham, J.-P., Kan, E., 2014. Heterogeneous Fenton degradation of bisphenol A by carbon nanotube-supported Fe3O4. Sep. Purif. Technol. 133, 388-395. https://doi.org/10.1016/j.seppur.2014.06.061

Erjavec, B., Kaplan, R., Djinović, P., Pintar, A., 2013. Catalytic wet air oxidation of bisphenol A model solution in a trickle-bed reactor over titanate nanotube-based catalysts. Appl. Catal. B Environ. 132-133, 342-352. https://doi.org/10.1016/j.apcatb.2012.12.007

Gültekin, I., Ince, N.H., 2007. Synthetic endocrine disruptors in the environment and water remediation by advanced oxidation processes. J. Environ. Manage. 85, 816-832. https://doi.org/10.1016/j.jenvman.2007.07.020 
Heponiemi, A., Azalim, S., Hu, T., Lassi, U., 2015. Cerium Oxide Based Catalysts for Wet Air Oxidation of Bisphenol A. Top. Catal. 58, 1043-1052. https://doi.org/10.1007/s11244-0150457-y

Kaplan, R., Erjavec, B., Senila, M., Pintar, A., 2014a. Catalytic wet air oxidation of bisphenol A solution in a batch-recycle trickle-bed reactor over titanate nanotube-based catalysts. Environ. Sci. Pollut. Res. 21, 11313-11319. https://doi.org/10.1007/s11356-014-3042-1

Kaplan, R., Erjavec, B., Senila, M., Pintar, A., 2014b. Catalytic wet air oxidation of bisphenol A solution in a batch-recycle trickle-bed reactor over titanate nanotube-based catalysts. Environ. Sci. Pollut. Res. Int. 21, 11313-11319. https://doi.org/10.1007/s11356-014-3042-1

Keav, S., de los Monteros, A.E., Barbier, J., Duprez, D., 2014. Wet Air Oxidation of phenol over Pt and $\mathrm{Ru}$ catalysts supported on cerium-based oxides: Resistance to fouling and kinetic modelling. Appl. Catal. B Environ. 150-151, 402-410. https://doi.org/10.1016/j.apcatb.2013.12.028

Kim, K.-H., Ihm, S.-K., 2011. Heterogeneous catalytic wet air oxidation of refractory organic pollutants in industrial wastewaters: A review. J. Hazard. Mater. 186, 16-34. https://doi.org/10.1016/j.jhazmat.2010.11.011

Lane, R.F., Adams, C.D., Randtke, S.J., Carter, R.E., 2015. Chlorination and chloramination of bisphenol A, bisphenol F, and bisphenol A diglycidyl ether in drinking water. Water Res. 79, 68-78. https://doi.org/10.1016/j.watres.2015.04.014

Lee, S., Liao, C., Song, G.-J., Ra, K., Kannan, K., Moon, H.-B., 2015. Emission of bisphenol analogues including bisphenol $\mathrm{A}$ and bisphenol $\mathrm{F}$ from wastewater treatment plants in Korea. Chemosphere 119, 1000-1006. https://doi.org/10.1016/j.chemosphere.2014.09.011

Levec, J., Pintar, A., 2007. Catalytic wet-air oxidation processes: A review. Catal. Today 124, 172184. https://doi.org/10.1016/j.cattod.2007.03.035

Lobos, J.H., Leib, T.K., Su, T.M., 1992. Biodegradation of bisphenol A and other bisphenols by a gram-negative aerobic bacterium. Appl. Environ. Microbiol. 58, 1823-1831.

Mirzaee, S.A., Jaafarzadeh, N., Jorfi, S., Gomes, H.T., Ahmadi, M., 2018. Enhanced degradation of Bisphenol A from high saline polycarbonate plant wastewater using wet air oxidation. Process Saf. Environ. Prot. 120, 321-330. https://doi.org/10.1016/j.psep.2018.09.021

Mohapatra, D.P., Brar, S.K., Tyagi, R.D., Surampalli, R.Y., 2010. Physico-chemical pre-treatment and biotransformation of wastewater and wastewater Sludge - Fate of bisphenol A. Chemosphere 78, 923-941. https://doi.org/10.1016/j.chemosphere.2009.12.053

Moussavi, G., Pourakbar, M., Shekoohiyan, S., Satari, M., 2018. The photochemical decomposition and detoxification of bisphenol A in the VUV/H2O2 process: Degradation, mineralization, 
and cytotoxicity assessment. Chem. Eng. J. 331, 755-764. https://doi.org/10.1016/j.cej.2017.09.009

Nousir, S., Keav, S., Barbier, J., Bensitel, M., Brahmi, R., Duprez, D., 2008. Deactivation phenomena during catalytic wet air oxidation (CWAO) of phenol over platinum catalysts supported on ceria and ceria-zirconia mixed oxides. Appl. Catal. B Environ. 84, 723-731. https://doi.org/10.1016/j.apcatb.2008.06.010

Omoike, A., Wacker, T., Navidonski, M., 2013. Biodegradation of bisphenol A by Heliscus lugdunensis, a naturally occurring hyphomycete in freshwater environments. Chemosphere 91, 1643-1647. https://doi.org/10.1016/j.chemosphere.2012.12.045

Pan, Z., Wang, R., Nie, Z., Chen, J., 2016. Effect of a second metal (Co, Fe, Mo and W) on performance of Ni2P/SiO2 for hydrodeoxygenation of methyl laurate. J. Energy Chem. 25, 418-426. https://doi.org/10.1016/j.jechem.2016.02.007

Pintar, A., Batista, J., Tišler, T., 2008. Catalytic wet-air oxidation of aqueous solutions of formic acid, acetic acid and phenol in a continuous-flow trickle-bed reactor over $\mathrm{Ru} / \mathrm{TiO} 2$ catalysts. Appl. Catal. B Environ. 84, 30-41. https://doi.org/10.1016/j.apcatb.2008.03.001

Rathnayake, B., Heponiemi, A., Huovinen, M., Ojala, S., Pirilä, M., Loikkanen, J., Azalim, S., Saouabe, M., Brahmi, R., Vähäkangas, K., Lassi, U., Keiski, R.L., 2019. Photocatalysis and catalytic wet air oxidation: Degradation and toxicity of bisphenol A containing wastewaters. Environ. Technol. 1-12. https://doi.org/10.1080/09593330.2019.1604817

Reddy, P.V.L., Kim, K.-H., 2015. A review of photochemical approaches for the treatment of a wide range of pesticides. J. Hazard. Mater. 285, 325-335. https://doi.org/10.1016/j.jhazmat.2014.11.036

Sasaki, M., Akahira, A., Oshiman, K., Tsuchido, T., Matsumura, Y., 2005a. Purification of Cytochrome P450 and Ferredoxin, Involved in Bisphenol A Degradation, from Sphingomonas sp. Strain AO1. Appl. Environ. Microbiol. 71, 8024-8030. https://doi.org/10.1128/AEM.71.12.8024-8030.2005

Sasaki, M., Maki, J., Oshiman, K., Matsumura, Y., Tsuchido, T., 2005b. Biodegradation of bisphenol A by cells and cell lysate from Sphingomonas sp. strain AO1. Biodegradation 16, 449-459. https://doi.org/10.1007/s10532-004-5023-4

Serra-Pérez, E., Álvarez-Torrellas, S., Ismael Águeda, V., Delgado, J.A., Ovejero, G., García, J., 2019. Insights into the removal of Bisphenol A by catalytic wet air oxidation upon carbon nanospheres-based catalysts: Key operating parameters, degradation intermediates and $\begin{array}{lllll}\text { reaction } & \text { pathway. }\end{array}$ https://doi.org/10.1016/j.apsusc.2018.12.205 
Sing, K.S.W., 1985. Reporting physisorption data for gas/solid systems with special reference to the determination of surface area and porosity (Recommendations 1984). Pure Appl. Chem. 57, 603-619. https://doi.org/10.1351/pac198557040603

Staples, C.A., Dome, P.B., Klecka, G.M., Oblock, S.T., Harris, L.R., 1998. A review of the environmental fate, effects, and exposures of bisphenol A. Chemosphere 36, 2149-2173. https://doi.org/10.1016/S0045-6535(97)10133-3

Tai, C., Jiang, G., Liu, Jingfu, Zhou, Q., Liu, Jiyan, 2005. Rapid degradation of bisphenol A using air as the oxidant catalyzed by polynuclear phthalocyanine complexes under visible light irradiation. J. Photochem. Photobiol. Chem. 172, 275-282. https://doi.org/10.1016/j.jphotochem.2004.12.015

Thommes, M., 2010. Physical Adsorption Characterization of Nanoporous Materials. Chem. Ing. Tech. 82, 1059-1073. https://doi.org/10.1002/cite.201000064

Vandenberg, L.N., Hauser, R., Marcus, M., Olea, N., Welshons, W.V., 2007. Human exposure to $\begin{array}{llllll}\text { bisphenol } & \text { A } & \text { (BPA). } & \text { Reprod. } & \text { Toxicol. } & \text { 24, }\end{array}$ https://doi.org/10.1016/j.reprotox.2007.07.010

Zbair, M., Ainassaari, K., El Assal, Z., Ojala, S., El Ouahedy, N., Keiski, R.L., Bensitel, M., Brahmi, R., 2018. Steam activation of waste biomass: highly microporous carbon, optimization of bisphenol A, and diuron adsorption by response surface methodology. Environ. Sci. Pollut. Res. 25, 35657-35671. https://doi.org/10.1007/s11356-018-3455-3

Zhang, Z., Huang, J., Xia, H., Dai, Q., Gu, Y., Lao, Y., Wang, X., 2018. Chlorinated volatile organic compound oxidation over SO42-/Fe2O3 catalysts. J. Catal. 360, 277-289. https://doi.org/10.1016/j.jcat.2017.11.024

Zou, X., Chen, T., Zhang, P., Chen, D., He, J., Dang, Y., Ma, Z., Chen, Y., Toloueinia, P., Zhu, C., Xie, J., Liu, H., Suib, S.L., 2018. High catalytic performance of Fe-Ni/Palygorskite in the steam reforming of toluene for hydrogen production. Appl. Energy 226, 827-837. https://doi.org/10.1016/j.apenergy.2018.06.005 